\title{
Removal of Zinc from Water by Adsorpion on Bentonite and Kaolin
}

\author{
By Manal Larakeb* \\ Leila Youcef ${ }^{\dagger}$ \\ Samia Achour
}

The aim of this work is to study the zinc removal possibility by adsorption on a bentonite of Mostaganem (Algeria) and kaolin, and determine various reaction parameter effects on the process. Experiments were carried out with synthetic distilled water solutions. The kinetics of adsorption results showed that zinc removal is max with $89.8 \%$ efficiency for bentonite after $20 \mathrm{~min}$ and $45.48 \%$ efficiency for kaolin after $60 \mathrm{~min}$ of contact time. Increasing in adsorbent dose $(0.5$ to $8 \mathrm{~g} / \mathrm{l})$ improves zinc removal efficiency for $5 \mathrm{mg} / \mathrm{l}$ like an initial concentration. Zinc removal efficiency by the two adsorbent decreases with the initial zinc concentration increasing (2 to $20 \mathrm{mg} / \mathrm{l}$ ). pH of treatment considerably affects the zinc retention rate. $\mathrm{Zn}$ removal efficiencies are noticeable at basic $\mathrm{pH}$. Whatever reaction parameter tested, it seems that bentonite is more effective than kaolin.

Keywords: Adsorption, Bentonite, Kaolin, Zinc.

\section{Introduction}

Generated industrial and urban wastewater often discharged into the receiving medium (seas, rivers, soils) without pretreatment, cause's environmental physical, chemical and biological quality degradation by several pollutants and generates many waterborne diseases (WHO, 1989; UNDP, 2006). Among those pollutants, we notice mineral pollutants, as heavy metals, where theirdensity exceeds $5 \mathrm{~g} / \mathrm{cm}^{3}$, which are usually present in the environment as traces: mercury, lead, cadmium, copper, arsenic, nickel, zinc, cobalt, manganese (Bernard, 1994). They have special chemical properties that provide them toxicity toward human beings as well as animal and vegetal kingdom living organisms, for which zinc is an essential element.

Proteins and enzymes containing zinc are involved in all metabolism aspects. Zinc excess can cause health problems, as stomach cramps, skin irritation, vomiting, nausea and anemia. WHO has set a maximum limit supply at $5 \mathrm{mg} / \mathrm{l}$ of zinc in drinking water (WHO, 2004). Wastewater in some Algerian industries contains zinc at levels widely above standards; such discharges can cause adverse effects toward aquatic flora and fauna. Many studies in Algeria have pointed such pollution danger concept, establishing that natural water

\footnotetext{
* Doctor, University of Biskra, Algeria.

${ }^{\dagger}$ Professor, University of Biskra, Algeria.

* Professor, University of Biskra, Algeria.
} 
reserves, in some areas close to industrial areas, where zinc is part of their discharge constitution, are contaminated (Derradji et al., 2003; Gaagai and Benchaiba, 2012).

Several methods have been used to remove zinc from water as membrane filtration (ultra-filtration, reverse osmosis, nano-filtration, electro-dialysis), chemical precipitation, ion exchange and electrochemical method (Degremont, 1989). Adsorption on clays has also proved its effectiveness, as in use of bentonite (Abdelouahab et al., 1987; Ferhat, 2012; Zhang et al., 2011; Sen and Gomez, 2011; Mohammed-Aziziand et al., 2013) or kaolin (Shahwan et al., 2005; Arias and Sen, 2009).

Therefore, the objective of this work is to study the bentonite of Mostaghanem (Algeria) and Kaolin effectiveness for zinc removal from synthetic distilled water solutions. Many reaction parameters were tested to optimize the process as contact time, effect of adsorbent dose, effect of initial zinc concentration and the $\mathrm{pH}$ of the treatment.

\section{Materials and Methods}

\section{Solutions of Zinc}

A $1000 \mathrm{mg} / \mathrm{l}$ of zinc stock solution was prepared in distilled water and stored away from light, while using zinc sulfate $\left(\mathrm{ZnSO}_{4}, 7 \mathrm{H}_{2} \mathrm{O}\right)$ as salt. Then, we dilute in different ratios to prepare lower solution concentrations used in tests.

\section{Adsorbents}

The two clays used as adsorbents in this study are:

- Bentonite: obtained from M'Zila (Mostaghanem (Algeria)) deposits. It is a calcic bentonite with $65 \mathrm{~m}^{2} / \mathrm{g}$ specific area. The characteristics of this bentonite are determined by the laboratory of the national company of mining products non ferrous (ENOF), as shown in Table 1.

- Kaolin $\left(\mathrm{Al}_{2} \mathrm{Si}_{2}(\mathrm{OH})_{4}\right)$ : It is an Aldrich product with $19.8 \mathrm{~m}^{2} / \mathrm{g}$ specific area.

Table 1. Physico-chemical Characteristics of the Bentonite of Mostaghanem (ENOF, 1997)

\begin{tabular}{|c|c|c|c|c|c|c|}
\cline { 2 - 6 } \multicolumn{1}{c|}{} & \multirow{2}{*}{ specific area $\left(\mathrm{m}^{2} / \mathrm{g}\right)$} & \multirow{2}{*}{$\mathrm{pH}$} & \multicolumn{4}{|c|}{$\begin{array}{c}\text { Exchangeable cations } \\
(\mathrm{méq} / 100 \mathrm{~g})\end{array}$} \\
\cline { 4 - 7 } & & & $\mathrm{Ca}^{2+}$ & $\mathrm{Mg}^{2+}$ & $\mathrm{Na}^{+}$ & $\mathrm{K}^{+}$ \\
\hline $\begin{array}{c}\text { Bentonite of } \\
\text { Mostaghanem }\end{array}$ & 65 & 9.1 & 43.6 & 4.2 & 25.2 & 6.0 \\
\hline
\end{tabular}




\section{Determination of Metal Concentration in Solutions}

An atomic absorption spectrometer (Shimadzu AA-6200) with hallow cathode lamp and air acetylene flame, was used for determining Zinc concentrations in water samples at a wave length of $\lambda=213.86 \mathrm{~nm}$.

\section{pH Measurement}

To measure $\mathrm{pH}$ of water samples, a $\mathrm{pH}$ meter (HANNApH210) was used. It is calibrated before any measurement series using two buffer solutions of $\mathrm{pH}$ 4.01and 9.18.

\section{Adsorption Test Description}

Tests of adsorption were carried out in a batch experiment. A known amount of the adsorbent was added to a solution of known initial concentration. The mixture was agitated on a magnetic stirrer. After filtration through a $0.45 \mathrm{~nm}$ membrane filter, the $\mathrm{pH}$ and the residual zinc concentration were measured for each filtered sample.

Several tests were performed to examine the effect of some parameters on zinc removal on any adsorbent such as stirring time( 0 to 6 hours), initial $\mathrm{Zn}^{2+}$ content (2 to $\left.20 \mathrm{mg} / \mathrm{l}\right)$, adsorbent dose $(0.5$ to $8 \mathrm{~g} / \mathrm{l})$ and $\mathrm{pH}$ of treatment (4 to 9$)$. $\mathrm{pH}$ of solutions was adjusted to the desired value by adding $\mathrm{HCl}(0.1 \mathrm{~N})$ or $\mathrm{NaOH}(0.1 \mathrm{~N})$ during adsorption test.

\section{Results and Discussion}

\section{Kinetic of Adsorption}

We followed the zinc removal efficiencies evolution as a contact time function (0 to6 hours) in synthetic distilled water solutions, containing initially $5 \mathrm{mg} / 1$ of zinc. $1 \mathrm{~g} / \mathrm{l}$ of the adsorbent that was introduced.-Obtained results (Figure 1) show that the zinc removal efficiency varies with the contact time.

Two stages can be differentiated by calculating the residual phosphate content in the solution as shown in Figure 1. The first stage shows an increase in the percentage of the $\mathrm{Zn}$ ions removal with an increasing contact time. Highest efficiency (89.8\%) is obtained after 20minutes for bentonite. By using kaolin as an adsorbent, highest zinc removal (45.48\%) corresponds to 60 minutes contact time. In the second stage, a decrease in the adsorption efficiency indicates the desorption of zinc ions by bentonite and kaolin. 
Figure 1. Kinetics Curve for Zinc (5mg/l) Removal using Bentonite and Kaolin

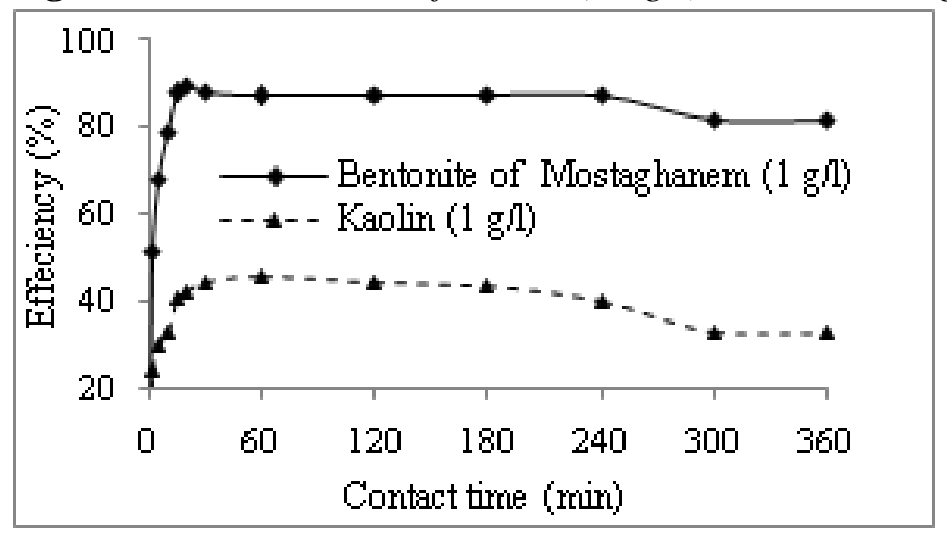

According to the study of Ferhat (2012), about heavy metals co-adsorption for modified bentonite in presence of mineral and organic flocculent, the $\mathrm{Zn}$ removal rate is almost total after only 20 minutes of agitation, exceeding $99 \%$ with an adsorption capacity corresponding to $26.4 \mathrm{mg} / \mathrm{g}$.

Arias et al (2009) indicated clearly that zinc metallic ion $\left(\mathrm{Zn}^{2+}\right)$ adsorption on Kaolin goes through two steps: a very rapid adsorption of $\mathrm{Zn}^{2+}$ at an external surface, followed by slow intra-particle diffusion inside an adsorbent. The equilibrium time is 60 minutes.

Zhang et al. (2011) have studied contact time effect on zinc removal by using raw bentonite (RB) and bentonite modified by calcium-hydroxide (ACB). Experiments were done by setting in contact a $\mathrm{Zn}^{2+}$ solution $(100 \mathrm{mg} / \mathrm{l})$ with adsorbent $(1 \mathrm{~g} / \mathrm{l})$ and adjusting $\mathrm{pH}$ at 6.5 . Results showed that activated bentonite can achieve $67 \%$ of removal after $5 \mathrm{~min}$ and reach $100 \%$ at 150 minutes of contact. Raw bentonite can achieve only $31 \%$ at 5 minutes and $40 \%$ at the end of experiment (480 minutes).

Bradl (2004) assumes that adsorption mechanisms include ion exchange (reaction and fixation). A reaction between $\mathrm{Zn}^{2+}$ andexchangeable cation on clay surface can be expressed by:

$$
\mathrm{nZn}^{2+}+2 \mathrm{M}^{\mathrm{n}+} \text {-Bentonite } \rightarrow 2 \mathrm{M}^{\mathrm{n}+}+\mathrm{nZn}^{2+} \text {-Bentonite }
$$

n: Exchangeable cation valence.

M: Exchangeable cation by bentonite as $\mathrm{Na}, \mathrm{K}, \mathrm{Mg}$ and $\mathrm{Ca}$.

\section{Modeling of Kinetics Adsorption}

In order to study the mechanism of adsorption and examine the process which controls the reaction, two kinetic models have been studied: The equation of Lagergren (Lagergren,1898) is a pseudo first order equation for adsorption in a liquid-solid system. It is represented as follows:

$$
\log \left(q_{e}-q_{t}\right)=\log q_{e}-\frac{k_{1}}{2,303} t
$$


$\mathrm{k}_{1}$ : is the constant speed of pseudo-first-order kinetics $\left(\mathrm{min}^{-1}\right)$.

$\mathrm{q}_{\mathrm{t}}, \mathrm{q}_{\mathrm{e}}$ : quantity of nitrate adsorbed at time $\mathrm{t}$, and at equilibrium $(\mathrm{mg} / \mathrm{g})$.

Values of $k_{1}$, qe and the coefficient of correlation $\left(\mathrm{R}^{2}\right)$ are determined from the slope and intercept of the curve of $\log$ (qe - qt) vs. $t$ (Figure 2). As shown in Table 2, a difference between the experimental adsorption capacity and the calculated one at the equilibrium of adsorption. This is also confirmed by a low adjustment of the experimental data to the pseudo-first order equation.

- The model of the pseudo-second order is presented by the following equation (Ho and Mc Kay, 2000):

$$
\frac{t}{q_{t}}=\frac{1}{K_{2} q_{e}^{2}}+\frac{1}{q_{e}} t
$$

$\mathrm{k}_{2}$ is the rate constant of the pseudo second order $\left(\mathrm{g} \mathrm{mol}^{-1} \mathrm{~min}^{-1}\right)$.

The kinetic parameters for this model are determined by plotting the curve $\mathrm{t} / \mathrm{q}$ vs. $\mathrm{t}$ (Figure 2). Unlike the previous model, the fit of the kinetic data using the pseudo-second-order equation has shown the existence of a good linearity with a high correlation $\left(\mathrm{R}^{2}>0.99\right)$ (Table 2). These results revealed that the kinetics of zinc adsorption fits well with the kinetic model of pseudo-second order for the two clays.

Figure 2. Pseudo-first-order and Pseudo-second-order Kinetic Models for Zn(II) Adsorption Kinetics on Clays $\left(\left[\mathrm{Zn}^{2+}\right]_{o}=5 \mathrm{mg} / \mathrm{l}\right.$; Adsorbent Dose $\left.=1 \mathrm{~g} / \mathrm{l}\right)$

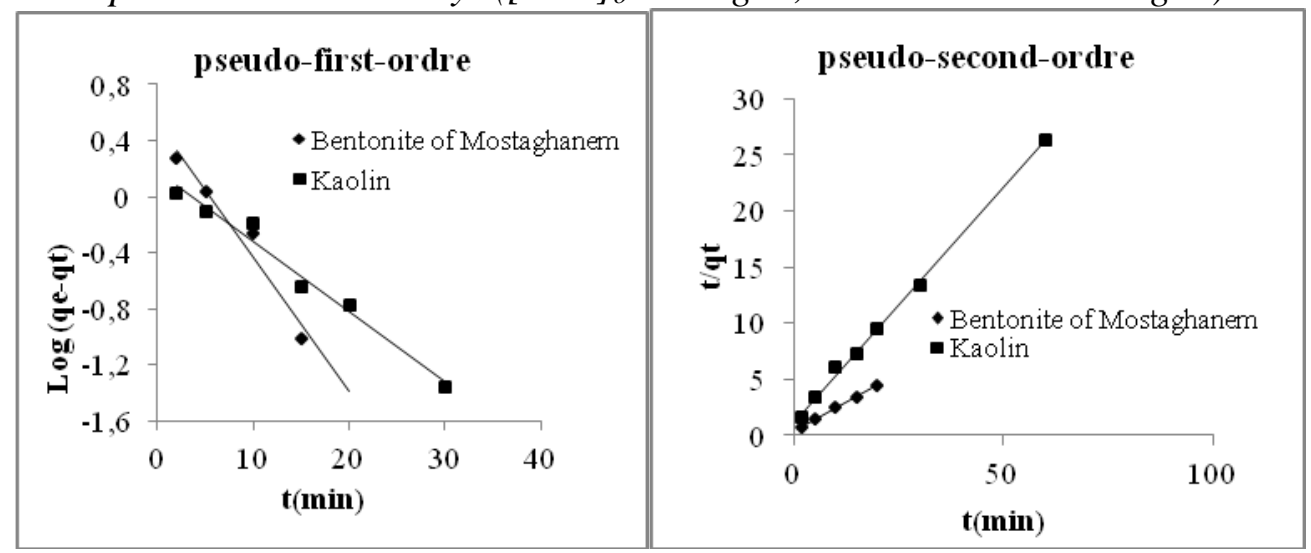


Table 2. The Kinetic Parameters for the Models of Adsorption of Zn (5 mg/) using Clays (Adsorbent Dose $=1 \mathrm{~g} / \mathrm{l}$ )

\begin{tabular}{|c|c|c|c|c|c|c|c|}
\hline \multirow[b]{2}{*}{ Clay } & \multirow[b]{2}{*}{$\begin{array}{c}\mathbf{q e}_{\text {exp }} \\
\text { mg/g) }\end{array}$} & \multicolumn{3}{|c|}{ Pseudo ${ }^{\text {st }}$ order model } & \multicolumn{3}{|c|}{ Pseudo $2^{\text {nd }}$ order model } \\
\hline & & $\begin{array}{c}\mathbf{K}_{\mathbf{1}} \\
(1 / \mathrm{min})\end{array}$ & $\underset{(\mathrm{mg} / \mathrm{g})}{\mathbf{q e}_{\mathrm{cal}}}$ & $\mathbf{R}^{2}$ & $\begin{array}{c}\text { qecal } \\
(\mathrm{mg} / \mathrm{g})\end{array}$ & $\underset{\text { (g/min.mg) }}{\mathbf{K}_{\mathbf{2}}}$ & $\mathbf{R}^{2}$ \\
\hline Bentonite of Mostaghanem & 3.65 & 0.2202 & 3.35 & 0.956 & 4.95 & 0.0949 & 0.998 \\
\hline Kaolin & 2.27 & 0.11149 & 1.49 & 0.977 & 2.39 & 0.1455 & 0.998 \\
\hline
\end{tabular}

According to Ferhat et al (2016) Evaluation of modified Algerian clay as mineral adsorbent was done for its adsorbing capacity on copper $(\mathrm{Cu})$ and Zinc (Zn) cations. The results obtained show a rapid kinetic adsorption for both metals (less than $2 \mathrm{~h}$ ) following the pseudo-second order model with high elimination rates of $67.2 \%$ and $61.8 \%$ for $\mathrm{Cu}$ and $\mathrm{Zn}$ respectively.

In the Works of Sen and Khoo (2013), the adsorptive properties of natural bentonite and kaolin clay minerals in the removal of zinc $\left(\mathrm{Zn}^{2+}\right)$ from aqueous solution have been studied by laboratory batch adsorption kinetic and equilibrium experiments. The result shows that Kinetic experiments clearly indicated that sorption of $\mathrm{Zn}$ (II) on both kaolin and bentonite is a two step process: a rapid adsorption of metal ion to the external surface followed by intra-particle diffusion into the interior of adsorbent. The kinetic studies revealed that the adsorption process followed the pseudo-second-order kinetics model.

\section{Effect of Adsorbent Dose}

The effect of the adsorbent dose on the removal of zinc was studied for the initial zinc concentration of $5 \mathrm{mg} / \mathrm{l}$. The dose of the adsorbent varied from 0.5 to $8 \mathrm{~g} / \mathrm{l}$ and the solutions where kept under stirring for 20 minutes in presence of bentonite and for 1 hour in presence of kaolin. The obtained results show that zinc removal efficiency increases with increasing of introduced adsorbent dose (Figure 3).

Figure 3. Effect of Clay Dose on Removal of Zinc $(5 \mathrm{mg} / \mathrm{l})$ (Bentonite: Contact Time $=20$ min; Kaolin: Contact Time $=1$ hr)

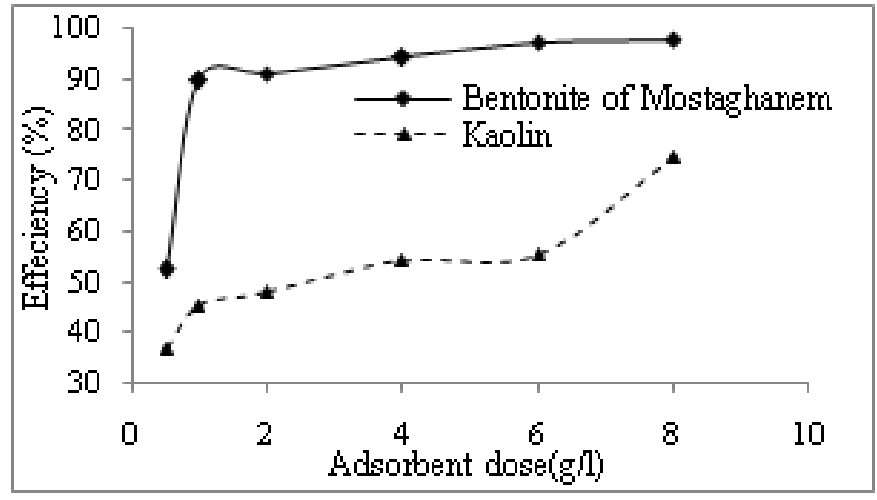


This efficiency improvement can be justified by the fact that the adsorbent dose increase allows for more supplementary zinc ion adsorption sites. The Same observation was done by certain authors. According to Zhang et al. (2011), zinc removal efficiency $(100 \mathrm{mg} / \mathrm{l})$ increases with bentonite dose increasing ( 0.2 to $2 \mathrm{~g} / \mathrm{l})$. Mishra and Patel (2009) found same result using kaolin $(5$ to $20 \mathrm{~g} / \mathrm{l})$ to treat distilled synthetic water solutions initially containing $100 \mathrm{mg} / \mathrm{l}$.

\section{Effect of Initial Concentration of Zinc}

After using $1 \mathrm{~g} / \mathrm{l}$ of adsorbent and varying initial ion metal concentration from 2 to $20 \mathrm{mg} / \mathrm{l}$, solutions were stirred during the contact time of $20 \mathrm{~min}$ and 60 min for bentonite and kaolin, respectively. According to the results shown in Figure 4, we can notice that the two curves represent the same rate. Treatment efficiency decreases with the initial zinc increasing. Efficiencies diminution could be due to the adsorption site saturation on the surface of clay. At higher concentrations, the available sites of adsorption become fewer and subsequently the removal of metal depends on the initial concentrations and decreases with increase in the initial metal ion concentration.

Figure 4. Effect of Initial Concentration in Removal of Zinc (Bentonite: Contact Time $=20 \mathrm{~min} ;$ Kaolin: Contact Time $=1 \mathrm{hr}$ )

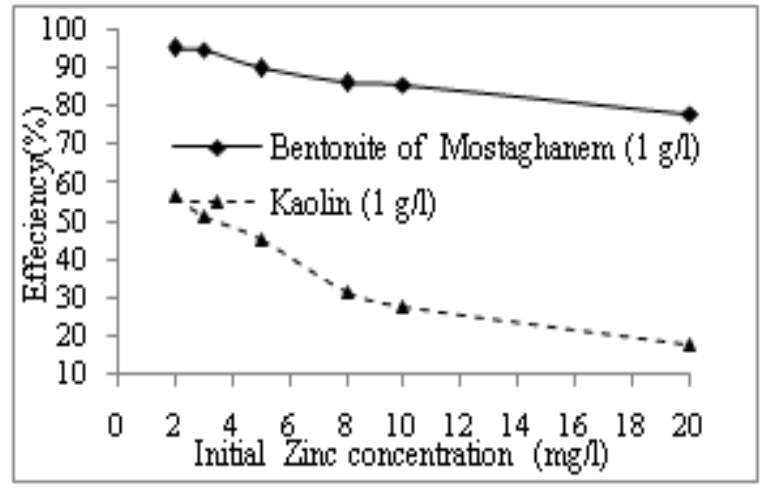

A same observation was made by Zhang et al. (2011) through the varying initial zinc (II) concentration ranging from 30 to $250 \mathrm{mg} / \mathrm{l}$ and using $1 \mathrm{~g} / \mathrm{l}$ of bentonite.

Shahwan et al. (2005) confirmed that kaolinite efficiency in zinc removal is noticeable at initial low levels $(1,100$ and $500 \mathrm{mg} / \mathrm{l})$ in this metal. Effectiveness diminishes progressively for initial zinc content from $1 \mathrm{mg} / \mathrm{l}$ to $10 \mathrm{mg} / \mathrm{l}$.

Through least-squares method adjustment, we obtain for each studied law and tested adsorbent, straight with correlation coefficients between $95 \%$ and 99\% (Figure 5). Various constants deduced from obtained straight equations are summarized in Table 3.

Linearized forms application of Freundlich and Langmuir laws allowed verifying that these two models are appropriate and the zinc removal 
efficiencies vary in the same way with both models. Behavioral differences seem to appear because of the maximum adsorption capacity $\mathrm{q}_{\mathrm{m}}$ for each adsorbent. The best adsorption capacity is obtained for bentonite $10.75 \mathrm{mg} / \mathrm{g}$, then $3.70 \mathrm{mg} / \mathrm{g}$ for kaolin (Table 3). Linearized forms of these models are expressed by (Richard, 1996):

Freundlich isotherm equation: $\log \frac{x}{m}=\log k+\frac{1}{n} \log C_{e}$

Langmuir isotherm equation: $\frac{m}{x}=\frac{1}{q_{m}}+\frac{1}{q_{m} \times b} \times \frac{1}{C_{e}}$

Ce: zinc concentration at equilibrium $(\mathrm{mg} / \mathrm{l})$

$\mathrm{x}=\left(\mathrm{C}_{0}-\mathrm{Ce}\right):$ Fixed zinc quantity $(\mathrm{mg} / \mathrm{l})$

$\mathrm{m}$ : Adsorbent mass (g)

$\mathrm{q}_{\mathrm{m}}$ : Ultimate adsorbent capacity $(\mathrm{mg} / \mathrm{g}$ )

$\mathrm{k}, \mathrm{n}, \mathrm{b}$ : Adsorption constants

Figure 5. Linear Forms of Langmuir and Freundlich Isotherms for Zinc Removal on Bentonite and Kaolin
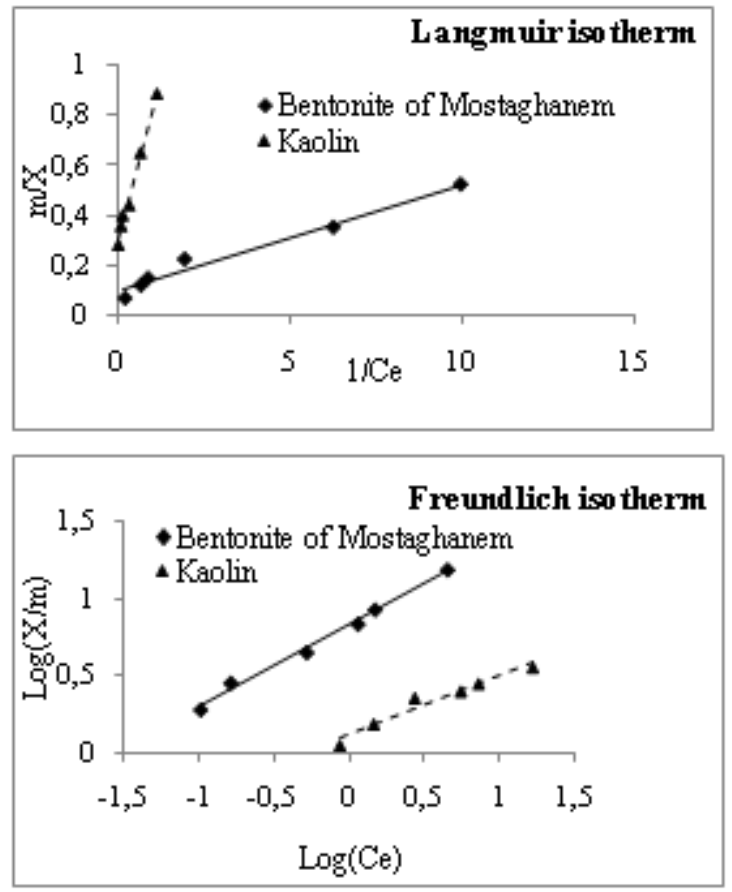

Table 3. Freundlich and Langmuir Parameters for Adsorption of $\mathrm{Zn}$ on Bentonite and Kaolin

\begin{tabular}{|c|c|c|c|c|c|c|}
\hline \multirow[b]{2}{*}{ Adsorbent } & \multicolumn{2}{|c|}{ Freundlich } & \multirow[b]{2}{*}{$\left(R^{2}\right)$} & \multicolumn{2}{|c|}{ Langmuir } & \multirow[b]{2}{*}{$\left(R^{2}\right)$} \\
\hline & n & $\mathbf{k}$ & & $\begin{array}{c}\mathbf{q}_{\mathbf{m}} \\
(\mathrm{mg} / \mathrm{g})\end{array}$ & $\begin{array}{c}\mathbf{b} \\
(\mathrm{l} / \mathrm{mg})\end{array}$ & \\
\hline Bentonite & 1.87 & 6.81 & 0.99 & 10.75 & 2.16 & 0.97 \\
\hline Kaolin & 2.65 & 1.32 & 0.95 & 3.70 & 0.50 & 0.99 \\
\hline
\end{tabular}




\section{Effect of $p H$}

Zinc adsorption experiments were conducted in presence of $1 \mathrm{~g} / 1$ of adsorbent and $5 \mathrm{mg} / \mathrm{l}$ of zinc. $\mathrm{pH}$ was adjusted to 4, 6, 7 and 9 successively and maintained constant during stirring time about $20 \mathrm{~min}$ and 01 hour for bentonite and Kaolin respectively, using $\mathrm{NaOH}$ and $\mathrm{HCl}$ solutions at $0.1 \mathrm{~N}$. The experiment results (Figure 6) shows a gradual increase in adsorption with increase of $\mathrm{pH}$ that may be due to the formation of $\mathrm{Zn}(\mathrm{OH})_{2}$. When using bentonite, greatest efficiencies are obtained in the basic media where best efficiency is at $\mathrm{pH} 9$ with a removal rate of $86.3 \%$. Even for kaolin, we noticed that the best efficiencies are obtained at basic $\mathrm{pH}$ where removal rate reaches $81.4 \%$ at $\mathrm{pH} 9$.

Figure 6. Effect of pH on Removal of Zinc $(5 \mathrm{mg} / \mathrm{l})$ by Adsorption on Bentonite and Kaolin (Bentonite: Contact Time $=20 \mathrm{~min}$; Kaolin: Contact Time=1 hr)

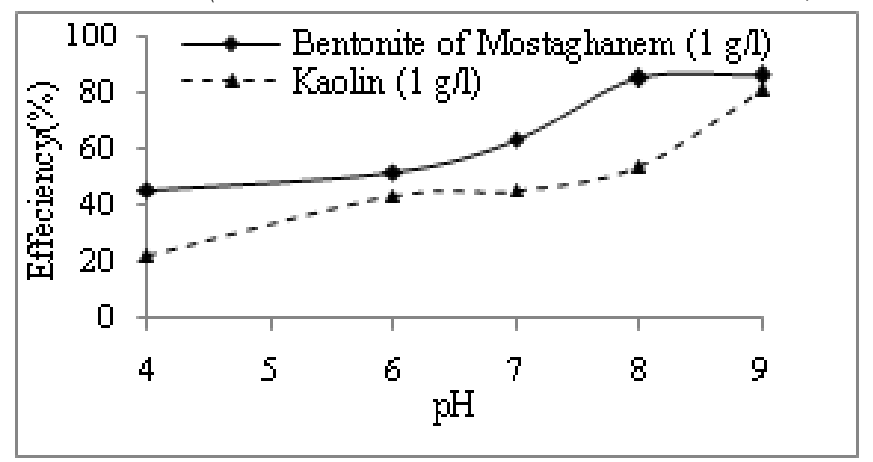

Experimental tests of Arias et al. (2009) and Mishara and Patel (2009) confirmed that zinc removal efficiency on kaolin increases with $\mathrm{pH}$ increasing. Sen and Gomez (2011) confirmed that there is an increase in zinc removal efficiency on natural bentonite with $\mathrm{pH}$ increasing. According to Abollino et al. (2003), metallic ions adsorption on sodic bentonite decreases with $\mathrm{pH}$ decreasing. At low $\mathrm{pH}$, hydrogen ions compete with heavy metals for surface sites. In addition, Si-O- and Al-O clustering are less deprotonated and hardly form complexes with divalent and trivalent ions. Zhang et al. (2011) showed that zinc removal by use of bentonite as adsorbent is strongly dependent on $\mathrm{pH}$. The removal percentage increases with $\mathrm{pH}$ increasing from 1 to 7 . Low efficiencies at $\mathrm{pH}<2$ may be due to competition increasing for adsorption sites between $\mathrm{H}^{+}$et $\mathrm{Zn}^{2+}$. By increasing the $\mathrm{pH}$, negative charges number increases sites which facilitate adsorption of more ions $\mathrm{Zn}^{2+}$. At $\mathrm{pH}>7, \mathrm{Zn}(\mathrm{OH})_{2}$ precipitation is the main actor in $\mathrm{Zn}^{2+}$ removal.

\section{Conclusions}

This work allowed study of different reactional parameters effect on zinc removal by adsorption on bentonite of Mostaghanem and Kaolin. Tests were 
made in synthetic distilled water solutions. Through all obtained results, we can deduce that:

- Equilibrium time after stirring is reached in $20 \mathrm{~min}$ and 01 hour for bentonite and Kaolin, respectively. The zinc ion uptake is reversible and the equation of pseudo-second-order is the appropriate model to describe the adsorption kinetics on bentonite and kaolin.

- Zinc removal efficiency increases with adsorbent dose increasing (0.5 to $8 \mathrm{~g} / \mathrm{l})$. For bentonite doses greater than $1 \mathrm{~g} / \mathrm{l}$, zinc removal efficiency exceeds $98 \%$. However, at 8g/l dose of kaolin, it only reaches $74.4 \%$.

- Zinc removal by adsorption on bentonite or Kaolin is more effective for water at low zinc concentration, because treatment efficiency decreases with initial zinc concentration increasing ( 2 to $20 \mathrm{mg} / \mathrm{l}$ ).

- Zinc adsorption is influenced by $\mathrm{pH}$ for both adsorbents. Best efficiencies were obtained at basic mediums.

According to this study results, adsorption capacity for zinc removal is more significant for bentonite of Mostaghanem than Kaolin, independently of reaction parameter variations (contact time, adsorbent dose, initial zinc content and $\mathrm{pH}$ of treatment).

\section{References}

Abdelouahab, C., Ait Amar, H., Obretenov, T.Z., Gaid, A. 1987. Fixation sur des argiles bentonitiques d'ions métalliques présents dans les eaux résiduaires industrielles. Cas du Cd(II) et du Zn(II) [Fixation on bentonitics clays of present metallic ions in industrial residual waters. Case of $\mathrm{Cd}(\mathrm{II})$ and $\mathrm{Zn}$ (II)]. International magazine of the Science of the water, $\mathrm{Vol} 3, \mathrm{n}^{\circ} 2,33-40$.

Abollino, O., Aceto, M., Malandrino, M., Sarzanini, C., Mentasti, E. 2003. Adsorption of heavy metals on Na-montmorillonite. Effect of $\mathrm{pH}$ and organic substances. Wat. Res, $\mathrm{n}^{\circ} 37,1619-1627$.

Arias, F., Sen, T. K. 2009. Removal of zinc metal ion $\left(\mathrm{Zn}^{2+}\right)$ from its aqueous solution by kaolin clay mineral: A kinetic and equilibrium study. Revue Source Colloids and surfaces A: Physicochemical and engineering aspects, $\mathrm{n}^{\circ} 348,100-108$.

Bernard, M. 1994. Cours de chimie minérale [Course of mineral chemistry]. $2^{\text {nd }}$ édition DUNOD, Paris.

Bradl, H. B. 2004. Adsorption of heavy metal ions on soils and soils constituents. J. Colloid Interface Sci, $\mathrm{n}^{\circ}$ 277, 1-18.

Degremont. 1989. Mémento technique de l'eau [Technico- Mémento of water]. $9^{\text {th }}$ Edition, Ed, Lavoisier, Paris.

Derradji, F., Kherici, N., Caruba, R., Romeo, M. 2003. Évaluation de la pollution chimique par le zinc et le fer de la nappe profonde des graviers d'Annaba (NordEst d'Algérie) [Evaluation of the chemical pollution by the zinc and the iron of the deep tablecloth of the gravels of Annaba (North East of Algeria)]. Books of l'ASEES, Vol 8, $\mathrm{n}^{\circ} 1,35-42$. 
ENOF, 1997. Rapport du laboratoire de Mostaganem [Report of the laboratory of Mostaganem]. National company of the non-ferrous mining products and useful substances.

Ferhat, M. 2012. Co-adsorption des métaux lourds sur la bentonite modifiée en présence de floculant minéral et biologique [Co-adsorption of heavy metals on the bentonite modified in the presence of mineral and biological floculant]. Memory of Magister in chemistry, Mouloud Mammeri university, Tizi-Ouzou. Algeria 120p.

Ferhat M., Kadouche S., Drouiche N., Messaoudi K., Messaoudi B., Lounici H. 2016. Competitive adsorption of toxic metals on bentonite and use of chitosan as flocculent coagulant to speed up the settling of generated clay suspensions. Chemosphere, $\mathrm{n}^{\circ}$ 165, 87-93.

Gaagai, A., Benchaiba, L. 2012. Eude de la pollution des eaux de surface du bassin versant du barrage de Babar sur Oued El Arab Est de l'Algérie [Study of surface water pollution of the pond of the dam of Babar on Oued El Arab- Est of Algeria]. Science lib editions Mersenne, Vol 4, $\mathrm{n}^{\circ} 120402$.

Ho Y. S., Ng J. Y., McKay G. 2000. Kinetics of pollutant sorption by biosorbents. Separation and purification methods, 29-2, 189-232.

Lagergren S. 1898. About the theory of so-called adsorption of soluble substances. Kungliga Svenska Vetens kaps akademiens. Handlingar, $\mathrm{n}^{\circ} 24$ (4), 1-39.

Mishra, P. C., Patel, R. K. 2009. Removal of lead and zinc ions from water by low cost adsorbents. Journal of Hazardous Material, $\mathrm{n}^{\circ} 168,319-325$.

Mohammed-Azizi F., Dib S., Boufatit M. 2013. Removal of heavy metals from aqueous solutions by Algerian bentonite. Desalination and Water Treatment, Vol 51, 4447-4458.

Richard Y.1980. Les traitements d'oxydation et d'adsorption pour la production d'eau [Oxidation and adsorption treatments for the production of water]. Conference University of Limoges. France.

Sen, T. K., Gomez, D. 2011. Adsorption of Zinc $\left(\mathrm{Zn}^{2+}\right)$ from aqueous solution on natural bentonite. Desalination, $\mathrm{n}^{\circ}$ 267, 286-294.

Sen, T. K., Khoo C. 2013. Adsorption Characteristics of Zinc $\left(\mathrm{Zn}^{2+}\right)$ from Aqueous Solution by Natural Bentonite and Kaolin Clay Minerals: A Comparative Study, Computational Water, Energy, and Environmental Engineering, $\mathrm{n}^{\circ} 2,1-6$.

Shahwan, T., Zunbul, B., Eroglu, A. E., Yilmaz, S. 2005.Effect of magnesium carbonate on the uptake of aqueous zinc and lead ions by natural kaolinite and clinoptilolite, Applied Clay Science, $\mathrm{n}^{\circ}$ 30, 209-218.

UNDP, 2006. Report on the Human Development. United Nations Development Program beyond the Shortage: power, Poverty and the World Crisis of the Water, New York.

WHO, 1989. Annual report on the Health in the World. Geneva.

WHO, 2004. Guidelines for drinking-water quality. Third edition, Volume 1Recommendation, Geneva.

Zhang, H., Tong, Z., Wei, T., Tang, Y. 2011. Removal characteristics of Zn(II) from aqueous solution by alkaline Ca-bentonite. Desalination $\mathrm{n}^{\circ} 276,103-108$. 
